\title{
BETWEEN ABJECTION AND WORLD-MAKING: SPATIAL DYNAMICS IN THE LIVES OF INDONESIAN WARIA*
}

\author{
TERJE TOOMISTU \\ Junior Research Fellow \\ Department of Ethnology \\ University of Tartu \\ Ülikooli 16, 51003 Tartu, Estonia \\ e-mail: terjetoomistu@gmail.com
}

\begin{abstract}
The lives of Indonesian waria (transgender women) are substantially shaped by spatial dynamics. As a result of social and spatial exclusion, subsequent migration and economic needs, a lifestyle pattern around daily work in beauty salons and street nightlife tied to transactional sex has evolved in many parts of urban Indonesia. Drawing on ethnographic research in the Indonesian regions of Java and West Papua, I demonstrate that despite tremendous spatial abjection, salons and street nightlife are also productive, transformative and conjoining spatialities that foster waria subjectivity in affective relations with their intimate partners, the community, the phantasmic promise of the transnational mediascape and Indonesia as a nation. The places that waria occupy may spark moral prejudice and targeted violence, but simultaneously they are sites of agency at which waria experience self-affirmation and a sense of belonging while embodying through gendered performance the envisioned mobility at both national and transnational scales. The paper thus foregrounds how spaces and subjectivities are mutually constitutive, forging one another, as well as how certain spatialities hold potential to disrupt the sense of marginality.
\end{abstract}

KEYWORDS: waria $\bullet$ transgender $\bullet$ Indonesia $\bullet$ space $\bullet$ abjection $\bullet$ subjectivity

\footnotetext{
* The research for this article was supported by the European Social Fund's Doctoral Studies and Internationalisation Programme DoRa carried out by the Archimedes Foundation. Foremost I would like to thank all my research participants in Indonesia. I would also like to thank the participants in the Writing Care reading group at the University of Amsterdam in Spring 2018 for their feedback on the initial draft of the manuscript, Art Leete, Dédé Oetomo, the copy editor of this paper, Daniel Allen; and the anonymous reviewers for their engaging feedback and helpful remarks.
} 


\section{N T RODUCTION}

Dari mana? Mau ke mana? - Where are you from? Where are you going? As the only visible foreigner on the overly crowded ferry cruising from Sulawesi to Papua, I was greeted with curious looks. It was the end of January, the time when people return from holidays on nearby islands to the 'land of fortune' - West Papua. People were not only sleeping in the designated sleeping areas, accommodating hundreds of people side by side, but on the stairs, in the corridors, and outside on deck under the blessing of the warm tropical wind. I noticed a young woman selling coffee and biscuits side by side with others who had laid out their delights on blankets and boxes. Her friendly smile and carefree interaction with customers caught my attention, and then her voice, which made me wonder whether she was a waria. I asked for a cup of coffee, took a seat nearby and soon we were involved in a conversation that went on for hours that day, the next day, and on long walks in Jayapura, the capital city of the district of Papua, Belinda's ${ }^{1}$ home for the past two years. I also realised Belinda was far from being the only waria onboard. There were several others traveling to Papua in search of happiness, with a plan to open their own salon. (FM: fieldwork diary 2012)

Waria are a visible group of people across Indonesian archipelago. They frequently describe themselves through specific distinction between their male body and the inner sense of gendered self, often referred to as the soul or heart of a woman. Soul (jiwa), which is aligned with mind-set, thoughts, feelings, behaviour, lays the foundation for their gendered subjectivity. It also indicates their wish to wear women's clothes and their desire for men. Most waria differentiate themselves from Indonesian gays, claiming that gays are attracted to other gays, but waria are attracted to men whom they consider heterosexual. Despite being a visible social category, especially in cities, they are far from being equally accepted in all spheres of society or recognised as respectable members of their families. These circumstances influence a substantial number of waria, who have histories of migration within Indonesia (as in the case presented in the extract of my fieldwork diary above), and to a lesser extent abroad. The tale of running away from a home village, from parents and family who refuse to accept them as waria, is a recurrent narrative among waria. In search of acceptance, recognition or anonymity, they travel to bigger cities such as Jakarta, Yogyakarta, Surabaya, Medan, Denpasar, Makassar. But waria migration is also tied to a certain sense of upward mobility, productivity and potential financial gain, which make West Papua and other urban regions of rapid economic growth attractive destinations.

The migratory trajectories are often supported by a widely shared lifestyle pattern among waria that includes daily work in a hair salon and night street sex work. As suggested in the Indonesia's Ministry of Health's research, an estimate of $76 \%$ of waria sell sex (Estimates and Projection... 2017). Based on my extended field work with waria, I suspect this to be an exaggeration. Although substantial differences between life-stories and self-identities among waria should not be overlooked, I however concur that the majority of waria have some experience of monetised sex exchange during their life course. In most larger cities, there are specific locations where waria of various age, but commonly between 18 and 40, gather every night and make themselves available for sexual services. While sexual labour provides the necessary income for many, pro- 
totypical waria employment since the 1970s is salon work (Boellstorff 2007: 87). The economic self-support model of salon and sex work largely also organises waria lives spatially. While the history of gender transgressive practices and subjectivities in the region dates to the pre-colonial era, the waria subject position can be traced back to late colonial market settings (ibid.: 85). However, its contemporary positionality rather emerged during the New Order (1965-1998), despite the state heteronormativity that appeared as the fundamental aspect of national modernity at the time (Hegarty 2018). Not only was the term waria - a derivation of the Indonesian words wanita ('woman') and pria ('man') - introduced during the New Order, but at that time waria also enthusiastically pursued the role of beauty purveyors, working in salons; and their visibility in the nocturnal cityscape also increased.

While waria form a recognisable part of modern Indonesian society, the dominant state discourses marginalise and repress practices outside the reproductive societal role. Since the late 1990s there has been a series of violent actions against gender and sexuality minorities (see Davies 2016) that are most vocally exercised by political Islamist groups, such as Front Pembela Islam (FPI; Islamic Defender's Front). In 2016, there was another wave of attacks that further mainstreamed the condemning discourse, indicating the politicisation of sexuality and the imposition of devout subjectivities. Waria street nightlife locations have also been targeted with municipal police raids, highlighting the tense context of surveillance of the sexual selves of waria, and non-heteronormative sex more generally. Recently the government has tried to eradicate prostitution in Indonesia and over a hundred designated female sex work areas (lokalisasi) have been closed (Solehudin 2018), which, through association with the issue of 'morality', puts waria nightlife under further pressure (see also Platt et al. 2018).

In 2014, the government of the Special Region of Yogyakarta (Daerah Istimewa Yogyakarta) passed a new law that aims to improve social welfare and prohibits begging and homelessness (Gubernur Daerah Istimewa... 2014). However, the implementation of the law also affected the widely shared waria practice of pengamen, that is, walking the streets and passing cafés or eateries (warung) while singing and playing a simple instrument and asking for some cash in return. For a number of waria, especially the older ones, busking is their sole means of income. Since the introduction of the law, police have been able to arrest waria for busking and send them to an assessment camp for a couple of months. These camps are potentially dangerous because of the spread of diseases such as tuberculosis, which is especially threatening for those waria who live with HIV (currently $24.8 \%$, see Indonesia IBBS 2015). The implementation of the 'beggar's law' not only reveals Indonesian progress-oriented ambitions, which include cleansing of the streets of the non-normative and dirty (Stodulka 2016: 247), but also underlines the spatial dimension of waria abjection more generally. Since the beginning of 2016 with the rise of denouncement of the LGBT population in Indonesian media, many waria feel threatened in public spaces, even to the point of cutting their hair and not wearing women's clothes in order to pass as men.

In this paper I pursue a spatial approach to waria subjectivities, unpacking the spatial dimension of their abjection as well as their agency. I draw on the conception of 'space' as used in recent work in critical human geography, influenced by theorists such as Henri Lefebvre (1991), Doreen Massey (1994), and Edward W. Soja (1996). Space in this understanding is socially and discursively produced, imbued with power relations, 
as opposed to seeing space as something static, measurable and absolute (Johnston and Longhurst 2010: 16). While in the field of feminist geography, a tendency to study place-making and mobility/movement separately has been noted (Gorman-Murray and Nash 2014: 638), this paper depicts these spatial processes as interwoven. The study foregrounds how non-normatively embodied subjects in Indonesia experience spatial abjection that forges mobility along with how they perceive and organise their lives spatially.

Waria lives are often structured by spatial constraints and subsequent movements, formulating over the course of migration, which may follow or precede an experience of 'transition' into dunia waria - a formulation that translates from Indonesian as 'the world of waria'. Waria often describe their lifeworld (Schutz and Luckmann 1973) in spatial terms as dunia waria. Following the wide use of this semantic formulation among waria, I deploy dunia waria to refer to the social and imaginary worlds of waria. Dunia waria is everything about waria - from fashion and communal traditions to the modes of interaction and self-reliance strategies and the spaces they occupy. Following its key spaces such as salons and the street nightlife locations, and related activities, the sense of dunia waria consequently shapes waria subjectivity across urban Indonesia drawing attention to the social and spatial dimension in the processes of becoming waria. In the same way that the ferry described in the diary extract above is the space of transition toward the land of opportunities and economic realisation in Papua, so dunia waria, with its codes of communication, self-stylisation and aesthetics, support strategies, ethics, and spaces, is often a transitional zone for young waria as they move toward self-affirmation and a feeling of belonging, fostering their experience and expression of subjectivity. This paper, hence, links to the queer geographies of the "quest for identity" (Knopp 2004: 122-123), in which "moving-out-to-come-out" experiences (GormanMurray and Nash 2014) create new places and simultaneously new ways of being. Moving to the urban regions of recent economic growth such as West Papua and working as beautifiers in salons, waria simultaneously become the enablers of progression, which is likewise stated through their embodied presence imbued with metropolitan imaginary at specific street sites at night. Thus the paper reveals how spaces and subjectivities are mutually constitutive, forging one another, as well as how certain spatialities may hold important potential to disrupt the sense of marginality.

The paper relies foremost on my intense fieldwork between 2010 and 2012 and a couple of follow-up visits up to 2018, spending altogether 17 months in Indonesia. I mainly worked in the cities of Yogyakarta and Surabaya in Java, and Sorong and Jayapura in West Papua (hereinafter Papua). Apart from participant observation and informal communication in beauty salons, nightlife locations and at cultural activities, I conducted 49 semi-structured biographical interviews with waria of various ages, interviewing some of them several times over the years. I conducted all interviews in Indonesian, apart from three conducted in English. There were some significant contextual differences between the key fieldwork sites, such as greater economic possibilities, the effects of migration, and the prevalence of racial tension in Papua; and greater competition in the beauty business, and historically more established communal activities and support networks in Java. These have been taken into account as they provide necessary ethnographic detail in support of the general argument of this paper. Focusing on waria in the aforementioned regions, this study interrogates various intersections of subjectivity, in 
which transgender positionality as well as transgressive sexuality, age and racialised embodiment tied to national belonging contribute to the forces of abjection of waria.

With the following, I first elaborate on the conceptual framework of this paper. This is proceeded by an overview of spatial abjection in waria lives, focussing on patterns of migration and structures of exclusion, which in turn influence the spatial organisation of dunia waria. In the next two sections, I elaborate on the ethnographic accounts of salon work and street nightlife as the key spaces of dunia waria. In the final section before the conclusions, I discuss the material by outlining how waria through their affectively engaged performance at these spaces contest the limitations of their social and spatial exclusion by enforcing their embodied world-making. While these practices hold significant promise, they are, however, still fragile and precarious ways of dealing with structural exclusions and spatial abjection.

\section{SPATIAL ABJECTION AND AGENCY}

Transgender subjectivity in the Western world was historically regarded as a subject in motion that is transitioning from one stable gender location to another. Significant changes split and pluralised this thinking at the beginning of the 1990s, causing the perversion-based models, produced by hegemonic medical and psychiatric discourses, to be replaced with frameworks that gave space to an appreciation of the diversity of human cultural practice (Rubin 2002: 17-18). Anthropology has made an important contribution to the criticism of medico-biological essentialism on gender by providing ethnographic studies on gendered variety and gender transgressive practices in various non-Western cultures (for example Johnson 1997; Boellstorff 2007; Blackwood 2010; Ochoa 2014). These accounts have deterred the linear thinking of transgender subjectivity. In transgender studies, Susan Stryker, Paisley Currah, and Lisa Jean Moore (2008: 14) have proposed reading "trans" rather than gender as the locus of analyses. Inspired by their quest to switch the modes of analyses between "the temporality of 'trans-' and the spatiality of '-gender,' and the spatiality of 'trans-' and the temporality of 'gender',"' I delineate the spatiality of waria-ness in urban Indonesia. While the spatiality of dunia waria revolves most tensely around certain spaces such as salons and nightlife locations, there is also an apparent temporal dimension in waria lives. The days of waria are often divided between an afternoon's work in salons, followed by washing (mandi), makeup and dressing up in feminine attire (déndong) after sunset and nightlife that might extend until sunrise. Furthermore, for a number of waria, their self-expression as waria, for which déndong is perhaps the most central (Hegarty 2018) element, is temporal. Some waria do not dress up in feminine attire during the day or in the presence of their immediate family, some have jobs where they are recognised by their male identity, some indeed only dress up for nightlife occasions a few times a week, or fewer.

I use the notion of abjection to analytically convey the various means and scales of social and spatial exclusion that waria face, from the individually experienced forms of rejection and physical or verbal abuse, to the more discursive productions and structural oppression within communities, regions, and the nation. While abjection literally means to expel, to cast out, Julia Kristeva in her Powers of Horror (1982) maintains that abjection is tied to questions of identity and social order. Viewing gender as a form of power, Judith Butler (1993: 7) notes, we are simultaneously subjected to gender and 
subjectivated by gender. Within the productive frames of regulatory power and performativity lies a continuous tension between what is coded as the norm and what is expelled as the abject. These renderings are crucial to note, since they define who one can and cannot be, who one can and cannot become. However, performativity's establishment of the normative body needs to be deployed alongside attention to the specific socio-spatial and historical embeddedness of the subject (Nelson 1999).

Abjection may manifest itself in the form of spatialisation by drawing borders between the self (i.e. clean, normal) and the other (i.e. dirty, abnormal) and by not allowing the other to enter spaces that construe the self (see also Johnston 2002: 84-88). Abjection as a practice of force (Nyers 2003: 1074) renders some subjects, such as the "gender outlaws" (Namaste 1996) or transgressive sexualities (Hubbard 1998), less worthy than others of sharing certain spaces. The spaces destined for the expelled subjects are the abject zones on the margins of society, such as the street nightlife by the river, on the railway, in the darkest corners, out of sight.

Conversely, access to or reimagined uses of certain spaces can enforce agency (see Sniekers 2017; Caillol 2018). Agency in the general feminist understanding refers to the capacity for autonomous action in a context, often entailing cultural sanctions and structural inequalities (McNay 2000: 10; Ahearn 2001). In poststructuralist feminist thinking, agency is not always understood as only arising in the negative paradigm of subjectivation, but rather, norms can be performed and experienced in various ways. Saba Mahmood (2011: 18) has demonstrated that agency does not necessarily convey resistance to domination, it can also refer to the capacity to act under specific relations of subordination. Subjugating oneself to certain practices - even seemingly in line with dominant discourse - can enforce subjectivity, providing a point from which to speak and socialise. In other words, specific forms of agency are embedded in the context in which they appear. In the case presented in this paper, I regard agency foremost as nested in the possibilities that arise from the expression of subjectivity.

Due to the prevailing heteronormativity and 'moral panic' around non-heteronormative sexualities in Indonesia (Platt et al. 2018), waria face relentless social and spatial exclusion that relegate them to the margins of society. Yet as a response to these forces, and as a survival strategy, waria continuously reinforce their embodied worldmaking in spaces and at times that are available for their use. Waria lives in and around dunia waria are imbued with affective engagements with various others, both physically nearby, such as their intimate partners and other waria, as well as imagined interactions with distant structuring ideals and available imagined communities (Anderson 2006 [1983]), enforcing their sense of self and belonging. Through performative practice at the spaces in which dunia waria unfolds, waria extend their affective engagements to the transnational imaginings of the cosmopolitan world in order to converge emotionally with the imagined 'phantasmic lady', which can be understood as the structuring ideal, an imagined counterpart worth striving for. There is also an evident sense of participation in dunia waria, which is envisioned as spreading across the archipelago and sharing ties with - and in particular with salon work also contributing to - the Indonesian nation. The following ethnographic analysis demonstrates how dunia waria appears as a transformative and conjoining spatiality that functions as both the medium and the outcome of situated human agency (Lefebvre 1991; Gregory et al. 2011: 716), providing strategies for more liveable lives (Butler 2009). 
Waria are a highly mobile segment of the population with many having some sort of history of migration within Indonesia. As of 2018, for example, there were 360 waria registered with Yogyakarta's Kebaya (an organisation focused on waria healthcare) database, yet only 182 were domiciled in the city. While some of the rest are based in neighbouring areas such as Sleman, the others are the nomadic part of the community, i.e. they come and go when travelling, with their main base in Yogyakarta.

One of the principal reasons for this lifestyle is economic. Whenever opportunities to make more money in other cities, or problems locally, appear, waria tend to move. Keliling-keliling - an Indonesian term often used in reference to the lifestyle of moving around cities looking for money, life experience and opportunities to change one's fate (merubah nasib) - is part of the life stories of many, especially when young and valued in the context of sex work markets (Hegarty 2017: 76-77).

Travel for economic reasons is especially apparent in urban Papua, where the majority of waria have travelled from elsewhere in search of better economic opportunities. The following examples from the vibrant port city of Sorong - often viewed as the gateway to Papua - foreground the sense of 'upward mobility' when moving to Papua. Milly (born 1983) had been in Sorong for two years, coming from a family of five children in East Java: "It's good here in Papua. While it's expensive, the life is nice because we can easily make money, unlike in Java where everything is cheap, but it's difficult to find money." (FM: 17.01.2012) Milly is a dedicated worker in her own salon, distancing herself from the local waria nightlife. She plans to return to her village once she succeeds ("jadi orang sukses"), as this is the expectation of her family who chased her away upon recognising her as a waria. Paulina (born 1973) came to Sorong six years ago from Makassar, Sulawesi, where she grew up in a family of seven children. After finishing high school, she earned a living in Bali for a couple of years working in salons, singing and giving massages to tourists. Later on she tried to run a salon in Makassar, but she was not satisfied. Eventually she moved to Sorong and opened a salon, considering this a move forward in her personal development ("ingin maju", FM: 23.01.2012). Since Paulina now has a boyfriend in Sorong, she has not made any plans to return to Makassar.

In contrast to the cases of Milly and Paulina, there are many whose migration is not justified 'professionally', but by a complicated upbringing, life on the streets and the sex work that may initially be a means of survival but which develops into a migratory lifestyle tied to subjectivity. Dewi (born 1970), for example, grew up in Ambon with her grandparents after her father left the family following the accusation that Dewi was not his son. To escape the shame, Dewi went to high school in Jakarta and later to college in Bandung to study tourism. There she discovered nightlife with other waria and realised herself as a waria. In 1997, she fell into drug use, mainly injecting synthetic heroin (putau). Over the following years she lived between Jakarta, Surabaya, Batam, Jambi, and Lampung surviving on sex work.

So I didn't use the knowledge that I got [from college], I didn't use it for something I had to do. I ignored it, because at that time I felt that this was my world. I hadn't found anything like this before, so I felt free. I had found my world. [Emphasis mine] I don't care, I don't care anymore about my future, about my life. (FM; Dewi, 18.01.2012) 
In 2006, Dewi began feeling sick and soon she was diagnosed with HIV. She was not surprised, since she had shared needles with friends whom she already saw dying. Her weight dropped to $28 \mathrm{~kg}$. After a few hard years being treated in Jakarta, she managed to regain her strength. She moved to Sorong, where she runs a salon with another waria.

Leaving home in search of identity, escaping judgemental, violent or otherwise uncomfortable disapproval of their desired gender expression has been a broad pattern among predominantly young waria. Others I met seek options for high school or a job in other cities for similar reasons. Due to the lack of support from their immediate families, access to usually costly higher education remains very limited. Having to survive on the streets in the bigger cities, young waria often earn their living by offering sexual services. Some waria prefer not to expose themselves to their immediate families, so they keep moving, while acting like heterosexual men in their villages. A few waria have the opportunity to travel abroad, mainly to Thailand, the Philippines and Malaysia, where they may also express themselves or share romantic lives with partners more freely.

In all these cases, waria take advantage of urban anonymity in a society that is otherwise heteronormative and communal. The patterns of family rejection highlight a crucial form of abjection that many waria face. In combination with other forms of social exclusion, stigma and violence, abjection relegates its subjects to the margins of society, to the abject spaces: the limited sphere of self-realisation, the anonymity of the larger cities, the times and places out of sight, of which the street nightlife is the most evident formation. The so-called 'LGBT crises' of the recent years has contributed significantly to these various forms of abjection. However, almost all the waria I know had experienced some forms of violence and diminishment long before. The condemning discourse on the LGBT population and acts of violence in certain regions, executed by groups such as the FPI, but also other conservative influencers and organisations, pursue the politically motivated agenda of 'Othering' LGBT subjects. This tactic subsequently feeds into the stigma and violent attitudes towards waria in potentially severe ways on the everyday level, making safety another reason to migrate. Most prevalently there has been a move away the more conservative regions such as Aceh, ${ }^{2}$ the only state in Indonesia practicing sharia.

As described, there are multiple yet often interlinked reasons for waria being mobile, from young waria who leave their towns or villages in search of identity to business-orientated ladies who seek better economic prospects. In some way or other, these reasons all relate to finding a space for acceptance and self-realisation, which is often sought and found in urban areas distant from immediate families. To paraphrase Dewi, they move in order to find their own world. The structural exclusions and the subsequent spatial abjection are hence crucial in influencing waria lives and thus need to be taken into account when addressing waria subjectivity and agency. In the next sections, I demonstrate how in the process of spatial abjection, waria simultaneously reclaim certain spaces that forge self-definition and community as well as the creative management of available resources. When telling their life stories, many young waria recount a moment of discovering or entering into dunia waria - a social and imaginary world that equips them with various attributes from ways to dress, talk and déndong, to the skills needed to survive, to the variety of cultural activities such as beauty pageants, birthday parties, community meetings, advocacy work. On a day-to-day level in many Indonesian cities, 
dunia waria spatially unfolds most notably at salons, where a number of waria work, and at specific street locations, where many waria spend their nights.

\section{SALON WORK}

Long before my active field research I was walking on the quiet streets in a small town in central Kalimantan. Suddenly, a splash of pink shimmered into view. I noticed the bright windows of a salon with pink walls and someone in the middle of it dancing to Indonesian popular folk music, all alone in a joyful dialogue with her image in the mirrors surrounding her. Some time later, I noticed similar scenes in other places in Indonesia - waria dancing in a salon, killing time in the lazy afternoon, swapping between hairstyling, cigarettes and dancing. (FM: fieldwork diary 2012)

When Ruly, a waria born in Sorong in 1966, went to study in Jakarta, she ended up helping out a waria friend who had a hair salon. After two years working in the friend's salon, and successfully completing a hairdressing course, Ruly returned to Sorong and opened the first salon run by a waria in the city, in 1991 (FM: 19.01.2015). While there are some salons in Sorong run by women, many are led by waria. Some of them are opened by waria in transit who leave a couple of months later when a newcomer takes over. Young waria who have just arrived in a new town, or recently discovered dunia waria for themselves, often help out other, older or more experienced waria in salons until they learn the necessary skills, find permanent jobs or even establish their own salons. The salon work commonly involves hairdressing and makeup services, sometimes also wedding makeup, seldom massage.

While salons function as important grounds for self-styling and socialisation, waria render salon work into meaningful ways of participating in and contributing to society in the course of their struggle for national belonging. Beautification is usually considered the core skill (ilmu) and talent of the waria - something they are known and needed for and what they often claim as their genuine contribution to Indonesian society. Tom Boellstorff (2007: 105) suggests that waria aspire to national belonging by contributing to society with 'good deeds'. In the waria discourse of recognition, salon work illustrates waria talent and their 'good deeds' for society, so that they can claim belonging to the nation by referring to their ability to transform others by 'making them beautiful'. This becomes especially evident in Papua, where the capability to make the Papuan population more 'beautiful' is often narrated as a justification for their presence. In contrast to the majority of Indonesians, indigenous Papuans are of Melanesian origin with relatively darker skin and curly hair. They are sometimes also depicted as backward (terbelakang) (Butt and Munro 2007). In turn, the availability of salon services is seen as a way of making Papua more modern, more 'Indonesian'. Beauty here is tied to the Indonesian notion of maju, that is, progress, advancement and maturity (see Toomistu 2019a). Hence, waria in Papua have established their economic niche as agents who can transform the local Papuan people into more progressive, more beautiful citizens.

Salons are also significant social venues where waria spend their days chatting, listening to music, dancing and practicing hairstyling skills on one another (see Figure 1). Salons are often the places where they dress up and curate their mood with music, 
drinks, and dancing before going out for the night. The walls in the salons are often covered with posters not only exhibiting various hairstyles, but also Western pop stars. Salons may hold community meetings and serve as homes or safe spaces for many waria (for latter, see Thajib 2018).

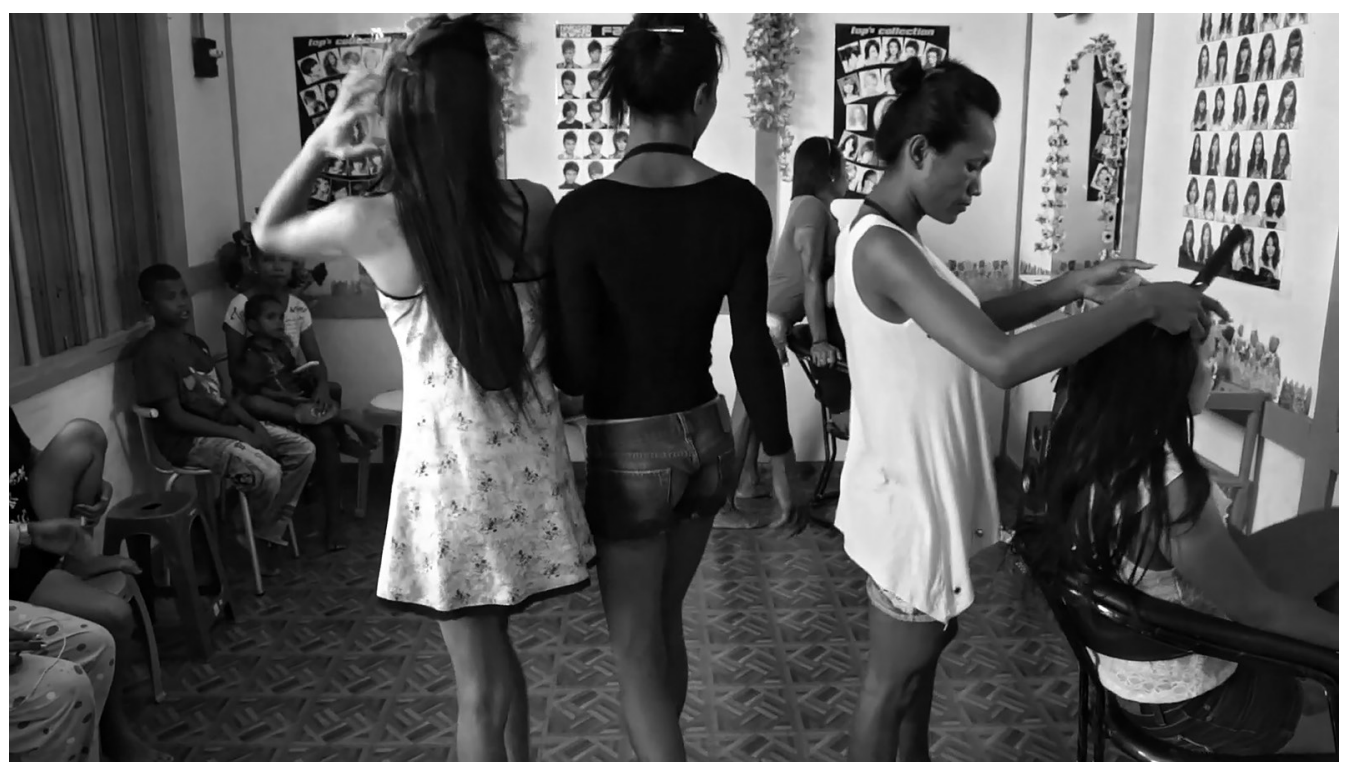

Photo 1. Waria socialising in a salon near Sorong, West Papua, 2015. The photograph is taken with the consent of those portrayed and does not purport to depict any of the individuals mentioned in the article. Photo by the author.

While waria regularly transform their clientele so that they are more 'beautiful', they also engage in constant transformation themselves as they dance, put on make-up, do their hair, try out poses. For example, about a week before the Miss Waria West Papua 2015 event in Sorong around 20 waria gathered at a salon belonging to their community leader. It was an educational event with a presentation on HIV/AIDS targeted at young waria, especially the small number of indigenous Papuan waria. After the presentation, waria began catwalking and playing in front of mirrors, making gestures and poses relating to their interpretation of Miss Mexico or Miss Belanda (Netherlands). The Papuan waria with slightly darker skin were called Miss Angola in reference to the Miss Universe 2011 pageant, which crowned Miss Angola the winner (The Washington Post 2011). Butler (1993: 14) has noted about gender performativity that "[t]he ideal that is mirrored depends on that very mirroring to be sustained as an ideal." When waria performed their imaginary Miss Universe in the salon, they were well aware that this was a momentary play, an exaggeration, a performance that rendered their faraway ideals into the fun of an experience here and now. Yet in its powerful metaphorical way, the corporeal imitation that waria enact in their play, positions them in motion toward the promise of the 'phantasmic lady'. 
Hence, besides providing basic income, waria salons engender the image of waria as useful in society for their beautification skills, which in some regions such as Papua fits well into the context of modernisation and 'development' and thus supports their quests for national belonging. But salons are also significant social sites for waria. Salons are productive and potentially transformative spatialities where waria affectively engage with their image, being in constant motion toward their gendered ideals, partaking in indefinite becoming. Participation in the gatherings and play at salons thus stimulate the sense of belonging to dunia waria as a specific circle of friends, as well as an imagined category of waria across the archipelago, both of which guide one's ways of becoming.

\section{STREET NIGHTLIFE}

Belinda told me her story when we met again in Jayapura. Her parents were from Ambon, the neighbouring island to Papua, although she grew up in Bali. When she left her hometown for high school in Denpasar, Belinda - then still a young man kept falling in love with men, who in turn didn't seem to notice Belinda's feelings. Soon she met other waria and discovered nightlife, which became the turning point of her life. "From there on I realised that my world is not so scary, it turned out also beautiful," she said. Even when she entered university and got a job in a pharmacy, she continued going out in Kuta to feel pretty and see other waria and men, who would make her feel happy. (FM: fieldwork diary 2012)

In most Indonesian cities with a waria population, there are specific places where waria gather at night for transactional sex as well as to socialise. While many waria are dependent on the income from sex work, nightlife also features socialisation, self-expression, and desire and is often the locus from which many young waria like Belinda and Dewi begin their self-discovery. Writing about abjection, Kristeva (1982: 3, emphasis original) noted: "I expel myself, I spit myself out, I abject myself within the same motion through which 'I' claim to establish myself'. As if in resonance with Kristeva's words, after discovering waria nightlife, Dewi left her studies and got carried away with nightly diversions. She claimed: "This is my world and I don't care about anything else!" (FM: 18.01.2012) Dewi abjected herself from society's mainstream along with its promises. And within the same motion she subjected herself to being waria, to the expression she recognised as her truest sense of being in the world. Moving between cities and relying on income from transactional sex for years, she outlived her gendered performance at the spaces waria had claimed for their street nightlife.

However, these places are the subject of moral prejudice and are sometimes targeted by municipal police (Satpol PP). Recent spatial dynamics of street sex work in Yogyakarta is exemplary of further spatial abjection. In around 2010, the busiest waria nocturnal hangout was in the city centre in front of the colonial bank building. Already by 2012 waria did not go to Bank Indonesia, or simply BI as waria call it, earlier than 2 AM due to recurrent raids. In 2015, the parking lot in front of the bank was re-arranged and the public toilet, where waria used to have sex with their clients, dismantled. By 2018, many waria in Yogyakarta considered street sex work dangerous and preferred to use online applications. Due to the raids and the public location of BI, which leaves waria in a vulnerable position for potential acts of violence, especially from 2016 onwards, 
only very few waria appear there. Coming out no earlier than $3 \mathrm{AM}$, these waria stated money as their sole reason for going there (FM: 28.10.2018). The social nature of the space beyond sex and money has nearly disappeared. Thus by 2018 , the single nightlife arena in Yogyakarta where numerous waria gathered was behind the railway station.

The area that is called Bong Suwung, or simply Bong, is not a specific waria hotspot, but a wider working class sex district that gets crowded with a few hundred people every evening after sunset. People mingle in the numerous warungs and chat on the rails, having to step aside with every passing train. It is known and respected that waria work at the eastern edge of the area, while female sex workers keep to the west. Each sex worker pays security personnel 10,000 RP (approx. 0.60 EUR) a night when working, so if there is a problem with the authorities the security has funds to pay bail. There are houses with small simple rooms available for rent.

Around 10 waria come every night, while Saturdays bring up to 50 waria. Most of the 'Saturday-night waria' have day jobs, so their main purpose for showing up is to socialise. However, if they notice an attractive man they might nevertheless proceed with monetised sex. In this regard, Bong and other waria nightlife locations across Indonesia function as important sites of self-expression and desire. For example, 29-year-old Betty, dressed in Korean-style short pants, arrived in Yogyakarta three months ago from Sulawesi. "In my kampung [village, neighbourhood], we don't have this!" she said, her eyes wide with excitement, referring to the crowds by the rails: "The atmosphere is good here, and friends support each other. In the village, you can only work in a salon." (FM: 28.10.2018)

While the social atmosphere is regarded as pleasant by older waria too, things look different from the point of economy. "Sometimes we are staying here waiting for guests [clients] until morning, sometimes there is no money," said Rina (FM: 03.11.2018), who has forgotten her age, but seems to be in her 50s. She came to Yogyakarta in the 1990s after growing up in Jakarta and moving through Surabaya and Semarang. As Benjamin Hegarty (2017: 76) also notes, waria migration to cities to make money through sexual labour rests on their youthful desirability and the perceived value of self. This explains the significant waria migration by suggesting a distinction between what they perceive as the productive and unproductive times of their lives and hence recognises migration as a means to an end while still young and desirable.

On one of the Saturday nights in Bong I hardly recognised Novita in a white sparkling mini dress. Novita sometimes comes here for outreach work, advising on safe sex. Meanwhile, she noted, she also has some fun. As we were chatting next to the rails, a man approached. I asked if he was of any interest to her. "Not really, but perhaps he is interested in me," she giggled, turning her back to the man (FM: 03.11.2018). Suddenly groups of ladies were running across the railway. Novita was gone in an instant, the loud music and the lights turned off. The men in warungs were nervous and not a single sex worker was in sight. Although we soon learned this raid emergency was a hoax, it is a familiar experience here. The raids, implemented by municipal or state police, occur every few months. If Novita had been caught, she would have spent the night in jail and paid a fine the next morning. There have been cases of violence and rape related to these arrests.

It is true that many waria engage in sex work for economic reasons (Ariyanto et al. 2007), but this leads to a one-sided understanding of waria nightlife. Most waria 
who participate in nightlife have side jobs. Every once in a while many young waria take pleasure in dressing up in flamboyant attire and going out. These practices might include sex, but often it is the waria who decides with whom to engage in sex and how to charge. While sexual pleasure and potentially long-lasting romantic relationships that often evolve from waria nightlife locations have been discussed in earlier studies (Toomistu 2019b), I focus here on the performative power that is manifest at these locations. While waria escape the normative assumptions of gendered embodiment (i.e. born male, becoming a man), they simultaneously subscribe to a different set of norms the norms of feminine beauty, reflected on the heterosexual matrix of the transnational mediascape (Appadurai 1996). The mimicry of the glamorous 'transnational gender' is often a survival strategy for those dependent on income from sex work. For others, these modalities provide a way to participate in wider cosmopolitan culture; for yet others it becomes the means of breaking away from the social order. Overall, in the spectacle of waria nightlife there is a great deal of gendered performance linked to the envisioned upward mobility in relation to Indonesian modernisation and consumer capitalist developments (see also Hegarty 2018). I am not saying that waria exchange the Indonesian normative feminine ideal with a glamorously global look, nor that they are performing a transgressive Indonesian ideal of the feminine. Indonesian gendered affects are always already in dialogue with global discourses (Saraswati 2010). Rather, it is important to recognise how the metropolitan imaginary feeds the embodied and pleasurable world-making at these nightlife spaces, opens up momentary engagements with the promise of global capitalism and consumption (Lindquist 2010: 290) and concurrently foregrounds waria visibility against the backdrop of "national glamour" (Hegarty 2018).

\section{UNDOING THE LIMITATIONS OF SOCIAL AND SPATIAL EXCLUSION}

At waria nightlife locations and in salons alike, spatiality turns into a vehicle for the fabrication of subjectivity. It is the poetics of space in practice, in the sense of what Edward Said (1979: 55) following Gaston Bachelard (1964 [1958]) has noted: "Space acquires emotional and even rational sense by a kind of poetic process, whereby the vacant or anonymous reaches of distance are converted into meaning for us here." For waria who déndong for the night or who play in front of mirrors in salons, these unfulfilled and distant aspirations can be envisioned as the 'phantasmic lady' who inspires their definition of beauty, femininity and sexiness, or simply informs their ways of becoming. The conception of the 'phantasmic lady' as the structuring ideal is as much individual as it is collective, resting on the currents of transnational media dubbed into Indonesian culture (Boellstorff 2003). Drawing on the media images that render global beauty pageants, pop stars, and lifestyle modes, waria reiterate these gendered symbols in the process of mimesis (Irigaray 1985 [1977]). They create their version of what José Esteban Muñoz (2009: 169) has referred to as the queer utopia where, in the process of reimagining the dominant signs and symbols through performance, "the limits of the here and now are traversed and transgressed". Similarly, based on the ballroom culture of Detroit, Marlon Bailey (2014) demonstrated how social displacement is nested in a sub- 
culture that creates spaces of communal celebration and support. Waria too make their street nightlife a space of joy and attraction, friendships and self-expression, where they are appreciated and desired the way they sometimes want to see themselves and the way they want to be loved. These spaces are never entirely safe, but they can be important sites of creativity and power (hooks 1999: 149). Marginal spaces are thus transformed into what hooks (1999) would call the 'spaces of radical openness' - for transformation, expression and community as well as for the practices of non-heteronormative intimacy. Through affectively engaged performance, waria undo the limitations of their social and spatial exclusion. They forge more liveable lives (Butler 2009) for themselves by sharing these spaces, using them for their financial benefit and simultaneously transforming themselves through the use of a chimeric metropolitan aesthetic and their relationship to the imagined community of Indonesian waria.

As shown, waria migrate either because they lack support and recognition from their immediate families, or they need money, although they also migrate to fight against these conditions. Waria perform sexual labour in order to survive, but their nightlife is equally as much about self-expression and the desire for intimacy. Waria work in salons, since there are not many other jobs available to them. However, by doing so they create their own spaces to socialise, practise their talent, strive for economic independence, and reclaim a position as part of the nation by highlighting their contribution to society. While waria are spatially abjected, this very spatial dynamics commits them to spatial formations that have agentic qualities - their spaces of embodied world-making. Affirming, declaring and sustaining their subjectivities in those spaces gives rise to the promise of more liveable lives.

This celebratory world-making through embodiment, however, is not equally available for all waria at all times. As shown above, access to erotic capital is usually tied to youthful desirability, making age a significant axis when considering the intersectional spatiality of waria. Furthermore, the sense of belonging, to the nation or otherwise, through enactments of beauty is much harder to achieve for indigenous Papuan waria, who stand further away from the dominant Indonesian beauty standard of fair skin and straight hair (see Saraswati 2010; Pausacker 2015; Toomistu 2019a). While indigenous Papuan waria, as described above, can be playfully labelled Miss Angola, they could not achieve the more desirable status of, for example, Miss Netherlands. Hence, the spatial abjection of waria needs to be reflected not only through the various scales it interrogates, but also through how it intersectionally affects waria within the diversity of the category.

\section{CONCLUSIONS}

I have described the spatiality of waria-ness in urban Indonesia through the notion of dunia waria and its key spaces, and the ways this spatiality is both the product of waria spatial abjection as well as the locus of becoming and a category of belonging for waria. Hence, the study contributes to the longstanding line of thinking in feminist geography of understanding bodies and spaces as forging one another. It also expands the still understudied field of non-western transgender spatialities. Analytical deployment of the notion of abjection to describe the various kinds of social exclusion and diminish- 
ment of waria enables a critique of the regulatory power of the norm. I engaged with the performativity framework, while emphasising the necessity of considering performatives as always spatially embedded, skewed by specific social and historical contexts. This obliges faithful attention to the specific forms of agency tied to certain places as well as how contexts affect subjects intersectionally.

I have hereby argued that waria lives are shaped by structural exclusions and subsequent spatial abjection, but the consequently formed spatiality of dunia waria reinforces waria agency by enabling their point of subjectivity. Of the various ways in which waria experience their embodied world-making, I focused on street nightlife and salons and their effect on mainly young waria. These spaces are not only places of paid exchange that matter in terms of waria personal economies, but are also productive spatialities that affirm and embrace waria subjectivities in affective relations with their intimate partners, the community, and the phantasmic promises of the transnational mediascape and Indonesian nation. These experiences matter, since they cater for self-affirmation and a sense of belonging. In short, abjected spaces for waria are also places of possibility and have agentic qualities.

While from that perspective, waria nightlife can be seen as the space of possibilities, it generally remains within the limited time of one's life course, it is not equally accessible for all waria and it is nevertheless subjected to continuous spatial abjection. The promising place-making outlined in the paper is still a precarious way of dealing with spatial abjection. The turn to online applications in search of money or intimacy, as exemplified with the case of waria street sex work in Yogyakarta, has the high potential to increase the already vulnerable state of waria. Street sex work, however dangerous it may be, has features of visibility and sociability, catering for communal support and (health)care by providing access to community resources and knowledge about safe sex, which is especially important for newcomers. Against the backdrop of urban redesign and the nationalist 'morality' project, the changing means of waria sex work is not only a symptom of changing technology, it also indicates the much deeper patterns of Indonesian spatial politics that demands continuous activist and scholarly attention. Ultimately it is not sufficient to rest with Dewi's declaration that "this is my world" as concerning only one's subjectivity within the abjected spheres on the margins of society. If we envisioned her statement as a claim from her point of subjectivity for space within her entangled kinships, the public space and the Indonesian national imaginary, what would it take to be able to call this "her world"? For subjects who are continuously pushed towards the outskirts of the Indonesian 'moral nation' project, nothing appears as crucial as the struggle for belonging.

\section{NOTES}

1 All names are pseudonyms.

2 On the complex ways in which waria negotiate their safety and safe spaces in Aceh, see Thajib 2018. 
$\mathrm{FM}=$ fieldwork materials of the author

Fieldwork diary, written in 2012.

Interviews cited:

Betty (pseud.), 28/10/2018, Yogyakarta

Dewi (pseud.), 18/01/2012, Sorong

Milly (pseud.), 17/01/2012, Sorong

Novi (pseud.), 03/11/2018, Yogyakarta

Paulina (pseud.), 23/01/2012, Sorong

Rina (pseud.), 03/11/2018, Yogyakarta

Ruly (pseud.), 19/01/2015, Sorong

\section{REFERENCES}

Ahearn, M. Laura. 2001. Language and Agency. - Annual Review of Anthropology 30: 109-137. DOI: https://doi.org/10.1146/annurev.anthro.30.1.109.

Anderson, Benedict. 2006 [1983]. Imagined Communities: Reflections on the Origin and Spread of Nationalism. Revised edn. London; New York, NY: Verso.

Appadurai, Arjun. 1996. Modernity At Large: Cultural Dimensions of Globalization. Minneapolis, MN; London: University of Minnesota Press.

Ariyanto, Rido Triawan; Suryadi A. Radjab and Eva K. Sundari. 2007. Hak kerja waria tanggung jawab negara. Jakarta: Arus Pelangi in association with Friedrich Ebert Stiftung.

Bachelard, Gaston. 1964 [1958]. The Poetics of Space, translated by Maria Jolas. New York, NY: Orion Press.

Bailey, M. Marlon. 2014. Engendering Space: Ballroom Culture and the Spatial Practice of Possibility in Detroit. - Gender, Place and Culture 21 (4): 489-507. DOI: https://doi.org/10.1080/096 6369X.2013.786688.

Blackwood, Evelyn. 2010. Falling into the Lesbi World Desire and Difference in Indonesia. Honolulu: University of Hawai'i Press. DOI: https://doi.org/10.21313/hawaii/9780824834425.001.0001.

Boellstorff, Tom. 2003. Dubbing Culture: Indonesian 'Gay' and 'Lesbi' Subjectivities and Ethnography in an Already Globalized World. - American Ethnologist 30 (2): 225-242. DOI: https:// doi.org/10.1525/ae.2003.30.2.225.

Boellstorff, Tom. 2007. A Coincidence of Desires: Anthropology, Queer Studies, Indonesia. Durham: Duke University Press. DOI: https://doi.org/10.1215/9780822389538.

Butler, Judith. 1993. Bodies That Matter: On the Discursive Limits of Sex. New York, NY: Routledge.

Butler, Judith. 2009. Undoing Gender. New York, NY: Routledge.

Butt, Leslie and Jenny Munro. 2007. Rebel Girls? Unplanned Pregnancy and Colonialism in Highlands Papua, Indonesia. - Culture, Health and Sexuality 9 (6): 585-598. DOI: https://doi. org/10.1080/13691050701515324.

Caillol, Daphné. 2018. The Spatial Dimension of Agency: The Everyday Urban Practices of Filipina Domestic Workers in Amman, Jordan. - Gender, Place and Culture 25 (5): 645-665. DOI: https://doi.org/10.1080/0966369X.2018.1472555.

Davies, Sarah Graham. 2016. Indonesia's Anti-LGBT Panic. - East Asia Forum 8 (2): 8-11.

Estimates and Projection... 2017. Estimates and Projections of HIV/AIDS in Indonesia 2015-2020. Jakarta: Directorate General of Disease Prevention and Control. Ministry of Health Republic Indonesia. http://www.depkes.go.id/resources/download/info-terkini/ESTIMATES_AND_ PROJECTION_OF_HIVAIDS_IN_INDONESIA_2015__2020.pdf (accessed June 30, 2019). 
Gorman-Murray, Andrew and Catherine J. Nash. 2014. Mobile Places, Relational Spaces: Conceptualizing Change in Sydney's LGBTQ Neighborhoods. - Environment and Planning D: Society and Space 32 (4): 622-641. DOI: https://doi.org/10.1068/d14012.

Gregory, Derek; Ron Johnston, Geraldine Pratt, Michael Watts and Sarah Whatmore, eds. 2011. The Dictionary of Human Geography. Hoboken, NJ: Wiley.

Gubernur Daerah Istimewa Yogyakarta. 2014. Peraturan Daerah Daerah Istimewa Yogyakarta Nomor 1 Tahun 2014 Tentang Penanganan Gelandangan dan Pengemis. https://peraturan. bpk.go.id/Home/Details/25699 (accessed October 4, 2019).

Hegarty, Benjamin. 2017. "When I Was Transgender": Visibility, Subjectivity, and Queer Aging in Indonesia. - Medicine Anthropology Theory 4 (2): 70-80. DOI: https://doi.org/10.17157/ mat.4.2.399.

Hegarty, Benjamin. 2018. Under the Lights, onto the Stage: Becoming Waria through National Glamour in New Order Indonesia. - TSQ: Transgender Studies Quarterly 5 (3): 355-377. DOI: https://doi.org/10.1215/23289252-6900738.

hooks, bell. 1999. Yearning: Race, Gender, and Cultural Politics. Cambridge, MA: South End Press.

Hubbard, Phil. 1998. Sexuality, Immorality and the City: Red-Light Districts and the Marginalisation of Female Street Prostitutes. - Gender, Place and Culture 5 (1): 55-76. DOI: https://doi. org/10.1080/09663699825322.

Indonesia IBBS. 2015. Ministry of Health Indonesia. Integrated Biological and Behavioral Survey (Survei Terpadu Biologis dan Perilaku). Unpublished research data. https://www.aidsdatahub. org/indonesia-country-slides-2019 (accessed October 4, 2019).

Irigaray, Lucy. 1985 [1977]. This Sex Which Is Not One, translated by Catherine Porter and Carolyn Burke. Ithaca, NY: Cornell University Press.

Johnson, Mark. 1997. Beauty and Power: Transgendering and Cultural Transformation in the Southern Philippines. Oxford; New York, NY: Berg.

Johnston, Lynda. 2002. Borderline Bodies. - Subjectivities, Knowledges, and Feminist Geographies, edited by Liz Bondi. Lanham, MD: Rowman and Littlefield, 75-89.

Johnston, Lynda and Robyn Longhurst. 2010. Space, Place, and Sex: Geographies of Sexualities. Lanham, MD: Rowman and Littlefield.

Knopp, Larry. 2004. Ontologies of Place, Placelessness, and Movement: Queer Quests for Identity and Their Impacts on Contemporary Geographic Thought. - Gender, Place and Culture 11 (1): 121-134. DOI: https://doi.org/10.1080/0966369042000188585.

Kristeva, Julia. 1982. Powers of Horror: An Essay on Abjection, translated by Leon S. Roudiez. New York, NY: Columbia University Press.

Lefebvre, Henri. 1991. The Production of Space. Hoboken, NJ: Wiley.

Lindquist, Johan. 2010. Putting Ecstasy to Work: Pleasure, Prostitution, and Inequality in the Indonesian Borderlands. - Identities: Global Studies in Culture and Power 17 (2-3): 280-303. DOI: https://doi.org/10.1080/10702891003733500.

Mahmood, Saba. 2011. Politics of Piety: The Islamic Revival and the Feminist Subject. Princeton, NJ: Princeton University Press. DOI: https://doi.org/10.2307/j.ctvct00cf.

Massey, Doreen. 1994. Space, Place, and Gender. Minneapolis, MN: University of Minnesota Press.

McNay, Lois. 2000. Gender and Agency: Reconfiguring the Subject in Feminist and Social Theory. Cambridge; Oxford: Polity Press.

Muñoz, José Esteban. 2009. Cruising Utopia: The Then and There of Queer Futurity. New York, NY: NYU Press.

Namaste, Ki. 1996. Genderbashing: Sexuality, Gender, and the Regulation of Public Space. - Environment and Planning D: Society and Space 14 (2): 221-240. DOI: https://doi.org/10.1068/d140221.

Nelson, Lise. 1999. Bodies (and Spaces) do Matter: The Limits of Performativity. - Gender, Place and Culture 6 (4): 331-353. DOI: https://doi.org/10.1080/09663699924926. 
Nyers, Peter. 2003. Abject Cosmopolitanism: The Politics of Protection in the Anti-Deportation Movement. - Third World Quarterly 24 (6): 1069-1093. DOI: https://doi.org/10.1080/01436590 310001630071.

Ochoa, Marcia. 2014. Queen for a Day: Transformistas, Beauty Queens, and the Performance of Femininity in Venezuela. Durham; London: Duke University Press. DOI: https://doi. org/10.1215/9780822376996.

Pausacker, Helen. 2015. Indonesian Beauty Queens: Embodying Ethnicity, Sexual Morality and the Nation. - Sex and Sexualities in Contemporary Indonesia: Sexual Politics, Health, Diversity and Representations, edited by Linda Rae Bennett and Sarah Graham Davies. London; New York, NY: Routledge, 273-292.

Platt, Maria; Sarah Graham Davies and Linda Rae Bennett. 2018. Contestations of Gender, Sexuality and Morality in Contemporary Indonesia. - Asian Studies Review 42 (1): 1-15. DOI: https:// doi.org/10.1080/10357823.2017.1409698.

Rubin, Gayle. 2002. Studying Sexual Subcultures: Excavating the Ethnography of Gay Communities in Urban North America. - Out in Theory: The Emergence of Lesbian and Gay Anthropology, edited by Ellen Lewin and William L. Leap. Urbana, MD; Chicago, IL: University of Illinois Press, 17-68. DOI: https://doi.org/10.5406/j.ctvvng2r.6.

Said, W. Edward. 1979. Orientalism. New York, NY: Vintage.

Saraswati, L. Ayu. 2010. Cosmopolitan Whiteness: The Effects and Affects of Skin-Whitening Advertisements in a Transnational Women's Magazine in Indonesia. - Meridians: Feminism, Race, Transnationalism 10 (2): 15-41. DOI: https://doi.org/10.2979/meridians.2010.10.2.15.

Schutz, Alfred and Thomas Luckmann. 1973. Structures of the Life-World 1. Evanston, IL: Northwestern University Press.

Sniekers, Marijke. 2017. Defining Dreams: Young Mothers' Agency in Constructions of Space. Social and Cultural Geography 19 (8): 1073-1096. DOI: https://doi.org/10.1080/14649365.2017.1 344872.

Soja, W. Edward. 1996. Thirdspace: Journeys to Los Angeles and Other Real-and-Imagined Places. Cambridge, MA: Blackwell Publishers.

Solehudin, Imam. 2018. Ratusan lokalisasi ditutup, mayoritas ada di provinsi ini [Hundreds of sex work districts were closed, the majority in this province]. - Jawa Pos, January 13. https:// www.jawapos.com/features/humaniora/13/01/2018/ratusan-lokalisasi-ditutup-mayoritasada-di-provinsi-ini/ (accessed February 4, 2018).

Stodulka, Thomas. 2016. Coming of Age on the Streets of Java: Coping with Marginality, Stigma and Illness. Bielefeld: Transcript. DOI: https://doi.org/10.14361/9783839436080.

Stryker, Susan; Paisley Currah and Lisa Jean Moore. 2008. Introduction: Trans-, Trans, or Transgender? - Women's Studies Quarterly 36 (3/4): 11-22. DOI: https://doi.org/10.1353/wsq.0.0112.

Thajib, Ferdiansyah. 2018. The Making and Breaking of Indonesian Muslim Queer Safe Spaces. - Borderlands 17 (1): 1-24.

The Washington Post. 2011. Miss Universe 2011 pageant crowns Miss Angola, Leila Lopes. - The Washington Post, September 13. https://www.washingtonpost.com/lifestyle/style/miss-universe-2011-pageant-crowns-miss-angola-leila-lopes/2011/09/13/gIQA5fwAQK_story.html (accessed December 10, 2017).

Toomistu, Terje. 2019a. Embodied Notions of Belonging: Practices of Beauty among Waria in West Papua, Indonesia. - Asian Studies Review 43 (4): 581-599. DOI: https://doi.org/10.1080/10 357823.2019.1657066.

Toomistu, Terje. 2019b. Playground Love: Sex Work, Pleasure, and Self-Affirmation in the Urban Nightlife of Indonesian Waria. - Culture, Health and Sexuality 21 (2): 205-218. DOI: https://doi. org/10.1080/13691058.2018.1459847. 